\title{
流量変動のインパクトを考慮した 河道内樹林動態の確率モデル \\ A STOCHASTIC MODEL FOR TREE VEGETATION DYNAMICS IN RIVER COURSES WITH INTERACTION BY DISCHARGE FLUCTUATION IMPACTS
}

宮本仁志 1 盛岡淳二 2 ・神田佳一 3 ・道奥康治 $4 \cdot$

魚谷拓矢 $5 \cdot$ 大地洋平 $2 \cdot$ 阿河一穂 ${ }^{2}$

Hitoshi MIYAMOTO, Junji MORIOKA, Keiichi KANDA, Kohji MICHIOKU, Takuya UOTANI, Yohei OHCHI and Kazuho AGA

\author{
1正会員 博 (工) 神戸大学准教授 工学研究科市民工学専攻 ( ₹657-8501 神戸市灘区六甲台町 1-1) \\ 2学生会員 神戸大学大学院工学研究科市民工学専攻 博士課程前期課程 ( 同上 ) \\ 3 正会員 博 (工) 舞鶴工業高等専門学校教授 建設システム工学科 († 625-8511 京都府舞鶴市字白屋234) \\ 4フェロー会員 工博 神戸大学教授 工学研究科市民工学専攻 (†657-8501 神戸市灘区六甲台町1-1) \\ 5学生会員 明石工業高等専門学校専攻科 建築・都市システム工学専攻 (†674-8501 明石市魚住町西岡679-3)
}

\begin{abstract}
Tree vegetation overgrowth in river courses has become a serious engineering issue for riparian management in Japan. In order to properly manage the river courses for both flood protection and ecological conservation, it would be necessary to accurately predict the tree vegetation dynamics for long-term duration. In this study, we developed a stochastic model for predicting the vegetation dynamics with emphasis on the interaction with flood events. In the model, the flood discharge was stochastically simulated using a filtered poison process, one of the popularly used approaches in hydrological time-series generation. The model included effects of vegetation growth, loss by the flood impact, and infant tree invasion. The results of Monte Carlo simulation quantitatively indicated that a suitable equilibrium state of tree vegetation density for both flood protection and ecological conservation was achieved by a certain flood level, and it was degraded as the flood impact became smaller.
\end{abstract}

Key Words: river environment, channel management, tree vegetation, river discharge, ecological model, Poisson process

\section{1. 序 論}

日本の多くの河川では1970年代以降, 砂州や高水敷で 樹木群落が拡大傾向を示し, 経年的な河道の樹林化が指 摘されている. この樹林化は，治水面では洪水流の流下 阻害となり, 環境面では河川が以前に有していた沿川生 態環境を大きく変質させるため, 河川環境管理上の課題 のひとつとして認識される.

樹林化に至る機構については，実河川を対象として土 砂移動と植生動態との関係1,2)やダムによる出水インパク 卜の機会減少3などからその形成過程が考察されている. さらに，洪水流や河床変動解析をあわせた樹林消長予測

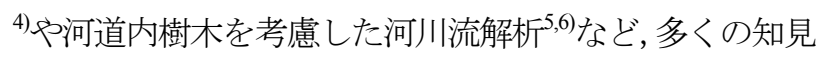
が得られている。これらの知見は，おもに個々の河道区 間での河川水理特性に焦点があてられたものである。 そ の一方で, 最近の気候変動研究7)からは将来の大規模出 水形態に有意な変化が予測されるが，そのような流量の
不確実性を考慮した河道内樹林の消長過程や流域にお ける樹林化河道の治水安全度評価に関しては未だ不明 の部分が大きい.

本研究では, 研究の全体フレームとして図-1に示す(1) 河川流量, (2)河川流動, (3)河床形状, (4)植生動態の 4 つ の水文・水理 - 生態過程の相互関連を考え, 流量の不確 実性を考慮した植生動態の確率モデルの構築を目指す. その中で，本論文では特に，(1)河川流量と(4)植生動態に 焦点をあててモデル化を試みる．流量時系列を確率的に 再現して出水を模擬生成するために, 流量に関してはポ アソン過程を仮定した確率過程モデル ${ }^{8,9}$ を使用する。一 方, 植生動態は出水のインパクトによる倒伏, 樹木の成

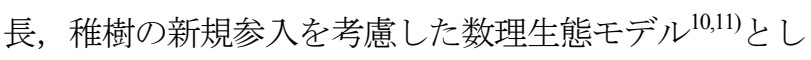
て定式化する.

本論文では一級河川加古川の樹木繁茂区間を対象に, 河道内樹木の現地調査結果と流量データを用いて確率 モデルのパラメーターを同定する. さらに，モンテカル 
ロシミュレーションによって流量規模の違いによる樹 林動態を確率評価し，モデルの基本性能を検討するとと もに今後の課題を議論する.

\section{2. 河道内樹林の現地観測}

本研究では, 図-2に示す一級水系加古川(流域面積: 1,730km², 幹川延長: $96 \mathrm{~km}$ )の河口距離23.2 23.8kmにお いて，2008年より継続的に河道内樹木の現地観測を実施 している．当該区間では特に右岸側の砂州で経年的に樹 林化が進行している. 植生の侵入状況と出水のインパク 卜を調査するために，観測開始当初に砂州上流部(23.6〜 $23.8 \mathrm{~km})$ を横断方向に三段階に切下げ施工し, 出水時に H-ADCPにより流速分布を計測するとともに河川流解析 を実施している5)。一方，砂州下流部(23.2〜23.6km)では 樹林帯が存置されている. 観測調査では砂州上を踏査し て個々のヤナギの位置をGPS で測定し, 胸高樹径, 樹高, 倒伏履歴の有無，さらに河床材料などを調べている. こ の砂州ではタチヤナギ・アカメヤナギなどヤナギ類と真 竹などタケ類が優先樹木である.

図-3に, 砂州下流部(23.2〜23.6km)におけるヤナギ類の 樹木分布と砂州地盤の平均水面からの比高分布を示す. この部分の砂州面積は約 $37,000 \mathrm{~m}^{2}$ であり, そこに 215 本の ヤナギが繁茂する. ヤナギは土壤水分条件のよい水際を 主にして砂州全般に広範に分布寸る. 胸高樹径や樹高な ど樹木サイズは水衝部の低水路側から冠水頻度の低い 堤防側に向けて徐々に大きくなる傾向がみられる. 本論 文では，このように砂州全般に繁茂するヤナギ類を対象 として，後述する植生動態モデルのパラメーターを同定 する. なお，もう一方の優先樹木である夕ケ類は，比高 の大きい堤防近くの砂州に竹林として偏在繁茂し，中小 規模出水による撹乱の影響が小さいため本論文では対 象とせず，モデルへの導入は今後の課題である.

流量に関する確率過程モデルのパラメーターを同定 するために，図-2に示す大島および万願寺観測所で記録 された1989〜2004年の日平均流量を用いる. これら二つ の観測所は現地観測地点の直下流に位置しており，本川 である大島観測所と支川の万願寺川での流量差を当該 現地観測地点の流量として使用寸る.

\section{3． 植生動態の確率モデル}

図-3に示すような樹木が全般的に繁茂する砂州を考 え, 経年的な植生変化を表現する数理モデルを定式化す る (図-1の (4))。植生サイズに関する数理生態モデル ${ }^{10,11)}$ をべースにして，河道内環境の著しい特徵である流量変 動を確率過程モデル ${ }^{8,9}$ )で表現することにより(図-1の(1)， 出水事象のインパクトによる樹木の倒伏の影響をモデ ルに組み込む。

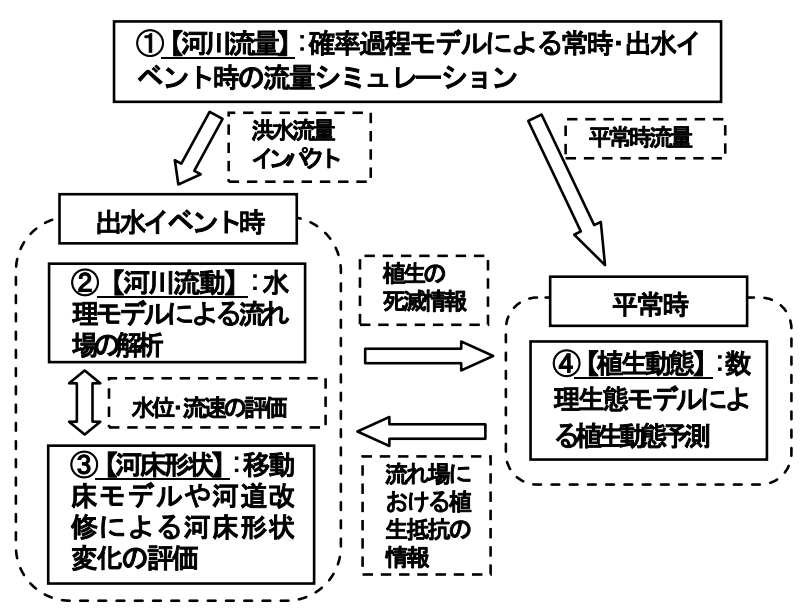

図-1 河道内植生動態に関連寸る水理・水文・生態過程

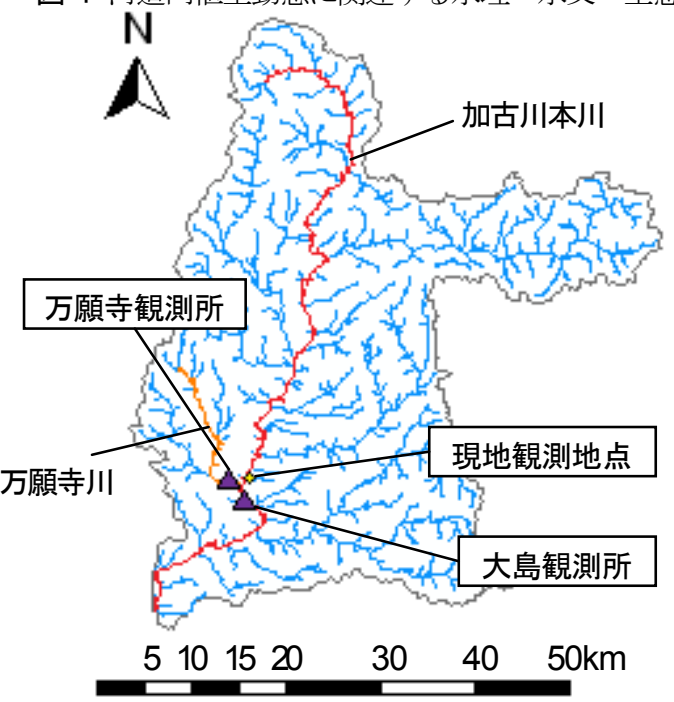

図-2 加古川流域の河道網と現地観測地点，流量観測所

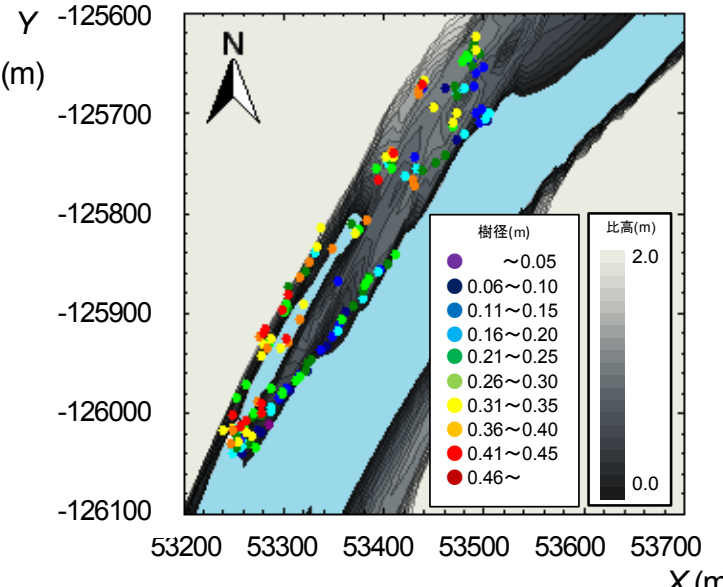

図-3 加古川観測地点における右岸砂州下流部のヤナ

ギ類の樹木分布と砂州比高(河口距離:23.2〜23.6km )

\section{（1）基礎方程式と境界条件・初期条件}

図-4に植生動態モデルの概要を示す．図-3のような樹 木が砂州全般に繁茂する状況をイメージし，砂州の単位 面積あたりの樹木サイズに関する分布密度 $n(x, t)$ の経時 変化を考える. (分布密度 $n(x, t)$ に関して例えば, 単位面積 $\left(\mathrm{m}^{2}\right)$ ・樹木サイズ $(\mathrm{cm})$ とすると本 $/ \mathrm{m}^{2} / \mathrm{cm}$ が単位となる). $n(x, t)$ は, 確率事象としてモデル化する流量変動(出水イ ベント)により消長を繰り返すので確率変数となる. 


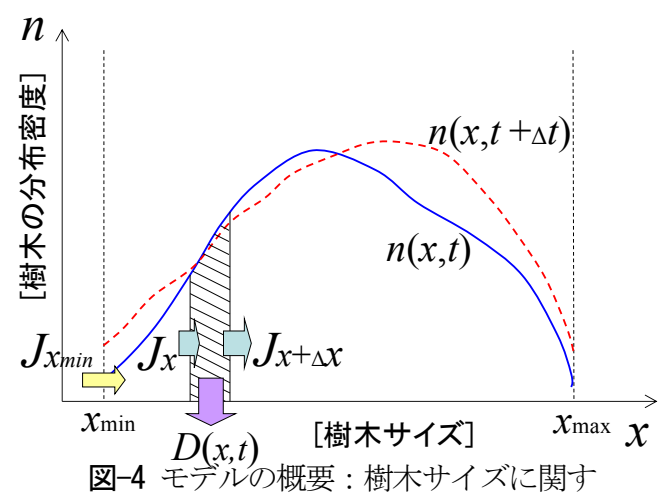

図-4 モデルの概要 : 樹木サイズに関す る樹木分布密度の経時変化とその要因

なお，砂州内における樹木位置の違いによる洪水イン パクトや土壌環境の変化の影響は, 後述する死亡率の分 布密度関数を用いたモデル化に代表されるように，確率 的に平面分布位置の影響を取り扱うことにする.

図-4に斜線で示す範囲 $(x, x+\Delta x)$ と時刻 $t$ における 樹木本数は,

$$
\int_{x}^{x+\Delta x} n(y, t) d y
$$

で与えられる．この樹木本数は，1)成長によるサイズ変 化 : 成長フラックス $J(x, t)$ と，2)出水イベントによる倒 伏 : 死亡率 $D(x, t)$ とに影響を受けて, 時刻 $t+\Delta t$ で新た な分布密度 $n(x, t+\Delta t)$ 一推移すると考えられる. 以上よ り，樹木本数の時間変化は次式で表される.

$$
\frac{d}{d t} \int_{x}^{x+\Delta x} n(y, t) d y=J(x, t)-J(x+\Delta x, t)-\int_{x}^{x+\Delta x} D(y, t) n(y, t) d y
$$

上式の両辺を $\Delta x$ で除して $\Delta x \rightarrow 0$ の極限をとると， $n(x, t)$ に関する以下の偏微分方程式が得られる.

$$
\frac{\partial n}{\partial t}=-\frac{\partial J}{\partial x}-D \cdot n
$$

さらに, サイズ $x$ の樹木一個体の平均的な成長速度を $g(x, t)$ とすると, 成長フラックス $J(x, t)$ は,

$$
J(x, t)=g(x, t) \cdot n(x, t)
$$

と表され，式(3)は以下のように書き直される.

$$
\frac{\partial n}{\partial t}=-\frac{\partial(g \cdot n)}{\partial x}-D \cdot n
$$

本論文では，樹木分布密度 $n(x, t)$ の経時変化を支配する 基礎方程式として式(5)を用いる. なお，ここまでの記述 では一般的な樹木サイズ $x$ を用いて式を誘導したが，本 論文における具体的な解析では，樹木サイズとして胸高 樹径 $d$ を採用している.

境界条件としては，図-4に示すように最小サイズ $x=$ $x_{\min }$ における稚樹の新規参入フラックス $J\left(x_{\min }, t\right)$ を与 える. 稚樹の新規参入は，出水イベントにより樹木が倒 伏して空きスペースになった砂州部分に侵入するもの とする. 新規参入の機会はヤナギの種子散布時期 ${ }^{12)}$ に必 ず一度発生し，それ以降当該年には新たに参入しないも のとして条件付きのポアソン過程でモデル化する.

以上より, $J\left(x_{\min }, t\right)$ は空きスペースの絶対量と植生密 度の両方に関係し，単位面積あたりの空きスペース $F_{S}(t)$ の自乗に比例すると考えて次式のように与える.

$$
J\left(x_{\text {min }}, t\right)=L \times F_{s}(t)^{2} / a\left(x_{\text {min }}\right)
$$

ここに,

$$
F_{s}(t)=1-\int_{x_{\min }}^{x_{\max }} a(x) n(x, t) d x
$$

$L$ : 参入後の生残率に関連する比例定数, $a\left(x_{\min }\right)$ : 砂州 単位面積・稚樹一個体あたりの砂州占有面積の割合, $a(x)$ : 砂州単位面積・サイズ $x$ の樹木一個体あたりの砂 州占有面積割合である．本論文で対象とするヤナギ類は 河岸に播種後の生残率が極めて低く ${ }^{13)}$, ここでは $L=0.01$ とした. 一方， $a(x)$ および $a\left(x_{\min }\right)$ は樹冠投影面積に比 例すると考え, ヤナギ類の樹木データ ${ }^{14)}$ より樹冠とサイ ズ $x$ (樹径 $d$ )の相関関係を解析して与える.

初期条件としては，図-3に示す加古川現地観測地点に おける樹木分布密度の実測值を正弦関数に近似して与 える.

\section{（2）成長速度と死亡率のモデル化}

\section{(a) 成長速度}

成長速度 $g(x, t)$ は，高木による低木への成長阻害を考 慮に入れて ${ }^{11)}$ ，実測データ ${ }^{14)}$ を用いて次式のような二次 曲線として定式化する.

$$
\begin{gathered}
g(x, t)=\alpha x(1-x / K(N(t))) \\
K\left(N_{L}\right)=x_{\text {max }} /\left(1+\beta N_{L}\right) \\
N_{L}(t)=\int_{x}^{x_{\max }} n(y, t) d y
\end{gathered}
$$

ここに, $\alpha, \beta$ : モデル定数, $K\left(N_{L}\right)$ : 成長阻害関数, $N_{L}$ : サイズ $\left(x \sim x_{\max }\right)$ となる高木の樹木本数である.

(b) 死亡率

本論文では，出水イベントによる樹木の死亡は主に倒 伏によると仮定する. 死亡率 $D(x, t)$ は，出水時に樹木に かかる倒伏モーメント $M$ と限界倒伏モーメント $M_{c}{ }^{14)}$ の比 $\gamma=M / M_{c}$ の関数として，正規分布の累積密度関数を 用いて次式のように与える.

$$
D=\int_{-\infty}^{\gamma} \frac{1}{\sqrt{2 \pi} \sigma} \exp \left[-\frac{(y-\mu)^{2}}{2 \sigma^{2}}\right] d y
$$

ここに， $\mu$ : 正規分布の期待值であり，ここでは $\mu=1.0$ と し,死亡率 $D$ が5割となる状態に対応する. 又, $\sigma$ ：砂州各 部において比高や河床材料などの違いによって生じる $M_{c}$ のバラツキを表す標準偏差であり，本論文では $\sigma=0.1$ を用いた. なお， $\sigma \rightarrow 0$ において丁度 $M=M_{c}$ を閾值と して倒伏・非倒伏が判定されることになる．こののに関 しては現在検証するためのデータがないため今後の検 討課題となり，ここでは実際に $\sigma$ の值を変えて感度分析 を行い, $\gamma=1.0$ のわりで極端な倒伏現象が生じないよう な状況を仮定して，有効数字 1 桁をとり， $\sigma=0.1$ とした.

出水時に樹木にかかる倒伏モーメント $M$ は，具体的 な河道横断面形状および次節で述べる確率流量 $Q$ のシ 


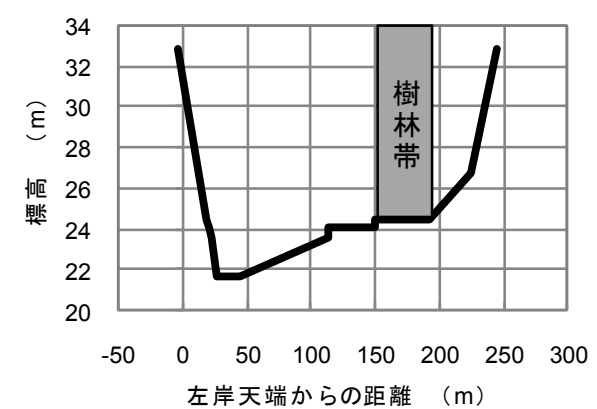

図-5 加古川観測地点における 疑似河道横断形状 $(23.6 \mathrm{~km})$

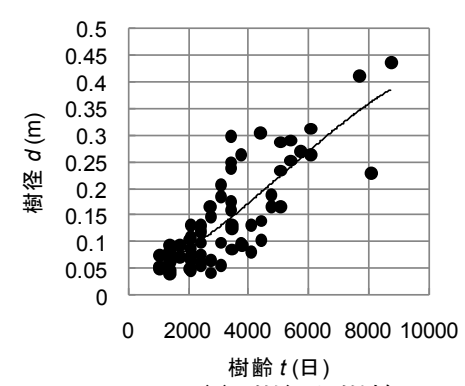

(a) 樹径と樹齢

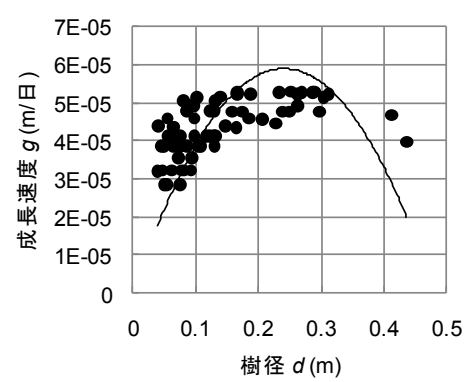

（b）成長速度と樹径

図-6 ヤナギ類の樹齢・樹径・成長速度の関係(成長阻害なしを仮定) 疑似河道横断形状 $(23.6 \mathrm{~km})$

合，そのモーメントを用いて以下の式から与えられる.

$$
E\left(Q_{j}\right)=v \theta / b
$$

それらを用いて以下の式(12)から算出する.

$$
M=1 / 4 \times \rho C_{D} d h^{2} v^{2}
$$

ここに, $\rho$ : 流体密度, $C_{D}$ : 樹木の抗力係数である.

図-5に，本論文で用いた加古川観測地点 (河口距離 $23.6 \mathrm{~km}$ ) における単純化された疑似河道横断形状を示す。 樹林化された砂州は左岸天端からの距離150～192mに位 置する. 河床勾配は1/800, 粗度係数は0.03. $C_{D}$ は 1.2 を与 えた. なお， $C_{D}$ は冠水/非冠水により樹冠部分の值が異な

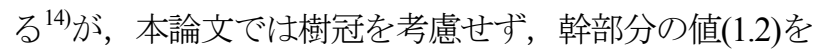
用いた．これにより，樹冠を考慮する時に比べて若干樹 木抗力を過大評価することになる. この樹冠の考慮は次 の段階での課題となる.

本論文では検討の初期段階として，上述のように流量 $Q$ から流速 $v$ ・水深 $h$ への変換 (図-1の(2)に対応)をマニ ング式によりごく単純に与えた。 しかしながら，樹木に よる水位の堰上効果などを正確に見積もるためには，樹 木抵抗などを陽に表現した運動量保存則による水理学 的モデル化が必要であり, これは次段階での研究課題と 位置付けている

\section{（3）流量の確率過程モデル}

図-1の(1)に対応する河川流量のモデルとして，本論文 ではショットノイズモデル ${ }^{8,9}$ を採用し，日平均流量の時 系列を確率過程で疑似生成する. ショットノイズモデル の詳細については理論から具体的なシミュレーション の実行手順まで, Weiss ${ }^{8)}$ により議論されている.

流量のショットノイズ過程は次式により定義される.

$$
Q(t)=\sum_{m=N(-\infty)}^{N(t)} y_{m} \exp \left[-b\left(t-\tau_{m}\right)\right]
$$

ここに, $N(t)$ : 単位時間あたりの出水事象の生起率が $v$ であるポアソン過程, $y_{m}$ : 降水により時刻 $\tau_{m}$ で起こり 始める出水の規模であり, 平均が $\theta$ の指数分布 $f(y)$ $=1 / \theta \exp (-y / \theta)$ に従う確率変数, $b$ : 出水事象の平均 減衰率である。

この過程に現れる三つのモデルパラメーター $(v, \theta$, $b$ ) は, 確率流量が $(1 / \theta, v / b)$ のガンマ分布(ピアソン II型) に従うことから, 日平均流量 $Q_{j}$ などの離散值の場

$$
\begin{gathered}
\operatorname{Var}\left(Q_{j}\right)=\frac{v \theta^{2}}{b} \frac{2\left[b-\left(1-e^{-b}\right)\right]}{b^{2}} \\
\rho\left(Q_{j}, Q_{j}+s\right)=\frac{\left(1-e^{-b}\right)^{2}}{2\left[b-\left(1-e^{-b}\right)\right]} e^{-b(s-1)}, \mathrm{s}>1
\end{gathered}
$$

ここに, $E\left(Q_{j}\right), \operatorname{Var}\left(Q_{j}\right), \rho\left(Q_{j}, Q_{j+s}\right)$ : それぞれ, $Q_{j}$ の 期待值, 分散, 自己相関関数である.

本論文では，梅雨や台風時の出水事象をより正確に再 現するために，月毎にモデルパラメーターの同定を行っ た.さらに，流量データをそのまま用いた初期段階の検 討では出水規模がよく再現されなかったため, 数值フィ ルター ${ }^{15)}$ を用いて流量を表面流出と地下水流出の二成分 に分離し，それぞれの成分にショットノイズモデルを適 用することにした。

\section{4. 結果と考察}

\section{（1） モデルパラメーターの同定}

\section{(a) 成長速度}

図-6にヤナギ類の樹齢・樹径・成長速度の関係を示す. 式(8)～(10)に示す成長速度の同定に際しては，成長速度 自体や成長阻害に関する観測データが入手困難であっ たそそのため，ひとまず成長阻害がないと仮定し，図-6 (a)に示すように樹齢と樹径の観測值 ${ }^{14)}$ を用いて両者の関 係を三次曲線で近似した．次に，得られた曲線を時間微 分して成長速度の次元に変換し，それより個々の観測值 に対応する成長速度の推定值を求めた(図-6(b)のプロッ 卜). これに基づいて式(8)のモデル定数 $\alpha$ を最小自乗法 により同定した． $\alpha$ の同定值は5.0×10-4゙ある. 図-6(b) に得られた成長速度曲線(成長阻害なし) を示す。一方, 式(9)の成長阻害関数中のパラメーター $\beta$ に関しては, 出 水のインパクトがない場合のシミュレーションによっ て感度分析を行い, 極相林の樹木サイズが最大值 $x_{\text {max }}$ に 集中しないような適正值 $\left(5.0 \times 10^{-4}\right)$ を与えた. なお，図-6 の観測值は寸でに砂州・樹林の環境特性が含まれている ため, 成長阻害なしの仮定は多少無理がある.これにつ いては次に述べる成長速度のバラツキの検討を含めて 

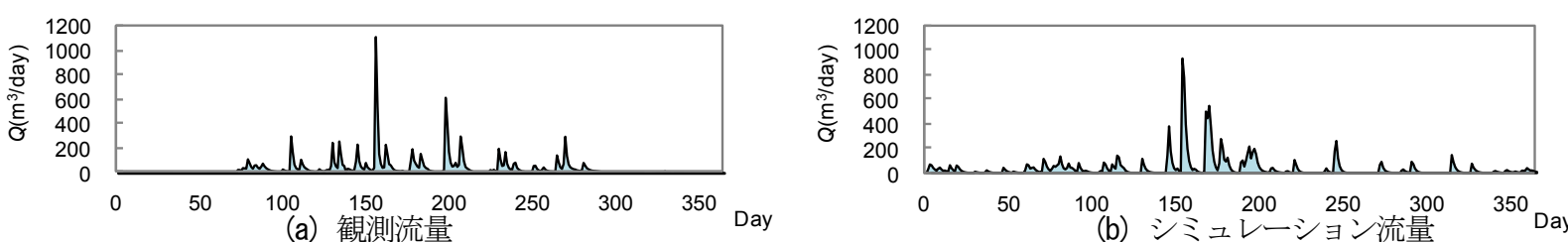

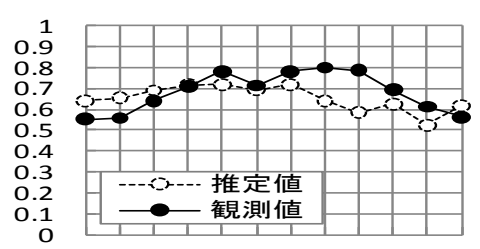

$\begin{array}{llllllllll}1 & 2 & 3 & 4 & 5 & 6 & 7 & 8 & 9 & 101112\end{array}$

(a) $b_{1}$

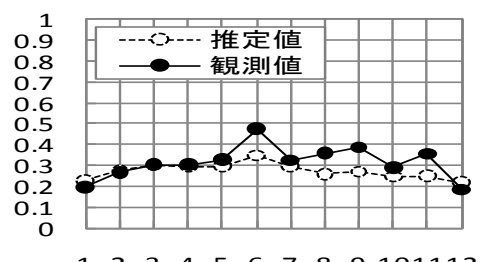

(d) $b_{2}$
図-7 ハイドログラフの例

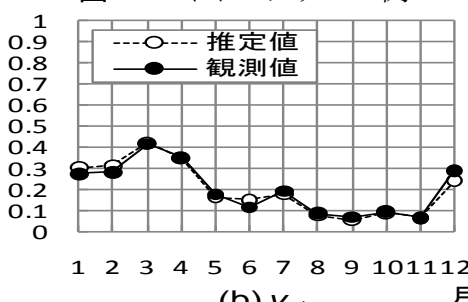

(b) $v_{1}$

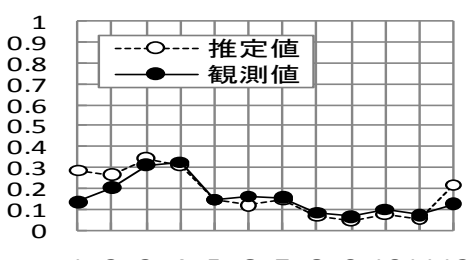

(e) $v_{2}$

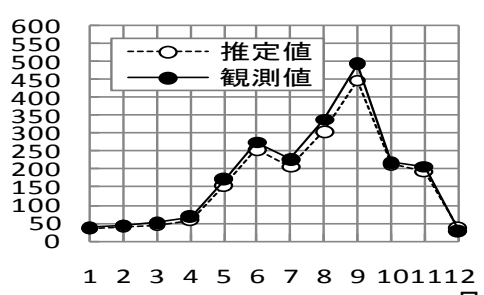

(c) $\theta_{1}$

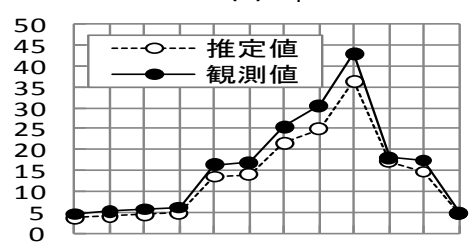

$\begin{array}{lllllllllll}1 & 2 & 3 & 4 & 5 & 6 & 7 & 8 & 9 & 101112\end{array}$

(f) $\theta_{2}$

図-8 ショットノイズモデルにおけるモデルパラメーター(パラメーターの下添字，1：直接流出成分，2：地下水流出成分）

観測データの蓄積を行い今後改良していく予定である.

本論文では樹木成長速度の平均を対象として定式化 を行ったが，図-6(a)に示すように同じ樹齢でも樹木サ イズに大きなバラツキがあることがわかる。この樹木成 長速度の分散は，全体としての砂州の樹林化進行に影響 寸ることが予想され ${ }^{10)}$ ，成長速度に関する系統的な観測 知見の蓄積と成長速度の分散のモデル化(フォッカ一・プ ランク方程式の導入 $\left.{ }^{10}\right)$ が今後の課題として考えられる.

\section{(b) 流量の確率過程モデル}

図-7に観測流量とシミュレーション流量のハイドロ グラフの一例を，図-8にショットノイズモデルにおける モデルパラメーターをそれぞれ示す。図-7より，ショッ トノイズモデルによって生成されたシミュレーション 流量の時系列は, 観測流量時系列の特徵をよく表現して いることがわかる. 図-8に示寸観測值は式(14)〜(16)によ り観測流量を用いて同定されたモデルパラメーターで あり，図-7(b)の流量ハイドログラフはこれらパラメー ターを用いて得られる。一方, 図-8の推定值は図-7 (b) のような流量シミュレーションを反復実行することに よって得られたモデルパラメーターの収束值である. 本 論文では，5000回のシミュレーションで各月・二成分の パラメーターがほぼ収束することが確認され，後述のモ ンテカルロシミュレーションではこの反復回数を採用 して解析を行う。図-8より, 観測值と推定值はほぼ同じ 值をとっており，確率過程モデルによる流量時系列の再 現性は高いことが確認される.

（2）植生動態シミュレーション(砂州切下げの影響評価) 図-9に，植生動態シミュレーションで得られた樹木サ イズに関する分布密度の経時変化を示寸．ここでは，図 -1の(3)に示した河床形状の変化に対応させて, 砂州を段
階的に切下げて 100 年間のシミュレーション行い，得ら れた分布密度の值を 10 年毎に示した. 図-9(a)の現状断 面のケースでは，時間経過とともに成長によってサイズ の大きい樹木の分布密度が大きくなり, 樹林化が進行し ている. 図-9(b)，(c)に示寸ような切下げを行ったケー スでは，樹林帯への出水のインパクトが増加することに よって樹木が死滅し，それにより生じた空きスペースに 稚樹が参入している．特に，図-9 (c) の $1.0 \mathrm{~m}$ 切り下げの ケースでは分布密度が非常に小さい值をとり，砂州の裸 地化が進行していることがわかる．さらに，この分布密 度を式(1)を用いて樹径全体で積分したものが単位面積 当たりの樹木本数となる. 計算結果により得られるその 最大值は図-9 (a)，（b)，（c)でそれぞれ0.018，0.016， 0.013 本 $/ \mathrm{m}^{2}$ となり，現地観測により得られる 0.017 本 $/ \mathrm{m}^{2}$ と同一オーダーの值をとる.

以上より，本論文で構築した確率モデルは植生動態の 経年的な変化傾向を表現できることが確認される。

\section{（3） 流量規模・切下げ量と樹林面積の関係}

次に，流量規模・切下げ量を変化させてモンテカルロ シミュレーションを行った. 図-9に示寸ような植生動態 シミュレーションを流量規模・切下げ量ごとに5000回実 行し，砂州上に占める樹林面積が $r \%$ 以下になる非超過 確率 $P(r)$ を評価した。図-10に結果を示す。これより，切 下げ量や流量規模が大きくなると $P(r)$ が増加し，樹木は 出水のたびに倒伏して定着しにくいため裸地が形成さ れや寸くなる，一方，流量規模が小さくなると $P(r)$ が減 少して樹林化の進行する確率が高くなることがわかる.

以上の確率評価の結果を用いて，本論文では樹林面積 率 $r か ゙$ 極端に高く $90 \%$ 以上になる場合を「樹林化」，逆に $10 \%$ 以下になる場合を「裸地化」と定義し，両者が平衡 


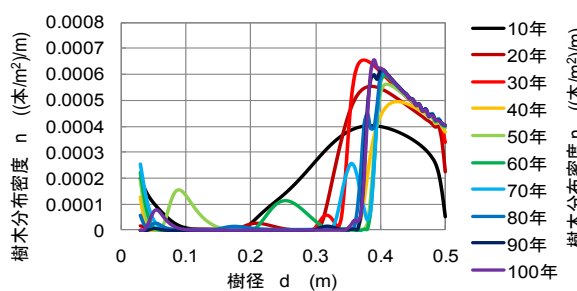

(a) 現状断面

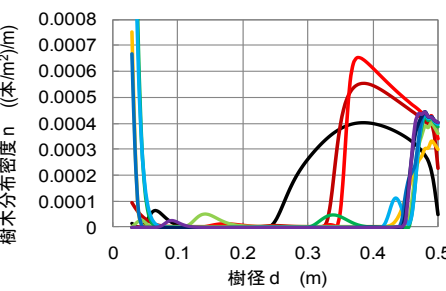

(b) $0.5 \mathrm{~m}$ 切下け
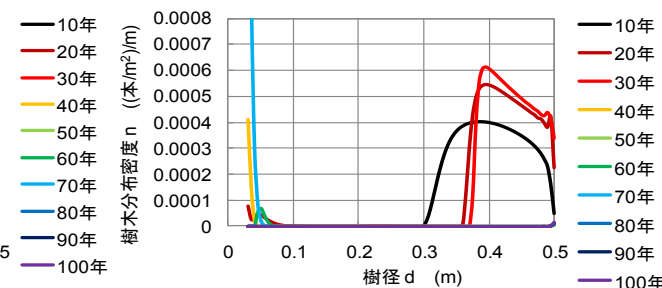

(c) $1.0 \mathrm{~m}$ 切下げ

図-9 植生動態シミュレーションによる樹木サイズに関する分布密度の経時変化(河道砂州切下げの影響解析結果)

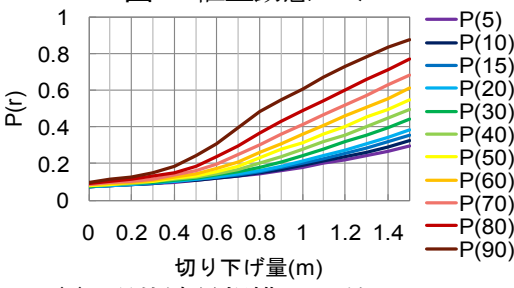

(a) 現状流量規模の 0.8 倍 $\left(Q_{0.8}\right)$

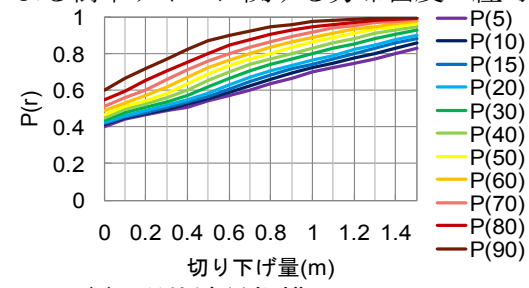

(b) 現状流量規模 $\left(Q_{1.0}\right)$

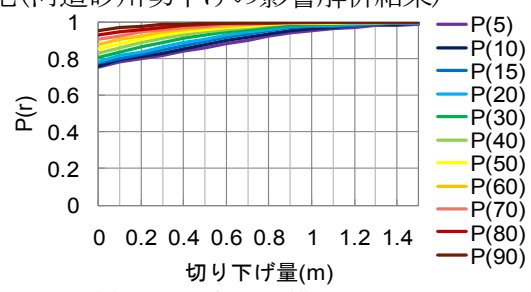

(c) 現状流量規模の 1.2 倍 $\left(Q_{1.2}\right)$

図-10 砂州上に占める樹林面積の非超過確率と流量規模・切下げ量の関係

する確率(環境平衡確率)を $\Delta P=P(90)-P(10)$ にって評 価した. 図-11に流量規模・切下げ量にともなう $\Delta P$ の変 化を示す. $\Delta P$ が大きいほど出水撹乱と樹林成長が動的 平衡を保ち, 適切な河道環境が維持されやすいと考えら れる. 図-11に示す流量規模が現状 $Q_{1.0}$ の場合, 切下げ量 を約 $0.5 \mathrm{~m}$ とすると $\Delta P$ が極大值 $\Delta P_{\max }$ をとり, 砂州が最適 な物理環境に維持されると判断される. 現状より流量規 模が小さくなる $Q_{0.9}, Q_{0.8}$ の場合は，切下げ量をより大 きくしないと $\Delta P_{\max }$ が現れず，現状の河道断面では樹林 化傾向と判断される. 逆に, 流量規模が大きい $Q_{1.1}$ の場 合はより小さい切下げ量で $\Delta P_{\max }$ が現れ， $Q_{1.2}$ の場合は $\Delta P_{\max }$ があらわれず裸地化傾向が強くなることがわかる.

\section{5. 結 論}

本論文では，流量の不確実性を考慮した植生動態の確 率モデルに関して，特に，河川流量と植生動態に焦点を あててモデルの構築を行った．加古川の樹木繁茂区間を 対象にモデルパラメーターを同定し，本モデルが流量規 模や河道断面の変化にともなう河道内樹林の経年的な 変化傾向を表現できることを確認した．今後，樹木抵抗 をモデル化した河川流動解析を本論文の植生動態モデ ルに組み込み，大規模出水時の水位と樹林消長を陽に評 価可能な統合モデルに発展させる予定である.

謝辞 : 本研究の実施にあたり, 神戸大学都市安全研究センター (H22プロジェクト研究, 代表: 宮本仁志), 河川整備基金 (No.22-1212-011, 代表: 道奥康治), 近畿建設協会(H22研究助成, 代表: 宮本仁志)から補助頂きました. 本研究の一部は, 加古川 の河道樹林化に関寸る研究会(明石高専, 神戸大学, 国交省姫路 河川国道事務所)の調査研究の一環として実施されました. 以上, 記して関係各位に謝意を表します。

\section{参考文献}

1) 清水, 小葉竹, 新船, 岡田: 磁床河川の河道内樹林化に関す る一考察, 水工学論文集, 第43巻, pp.971-976, 1999.

2) 李, 藤田, 山本: 礫床河道における安定植生域拡大のシナリ 才 - 多摩川上流部を対象にした事例分析より -, 水工学論 文集, 第43巻, pp.977-982, 1999.

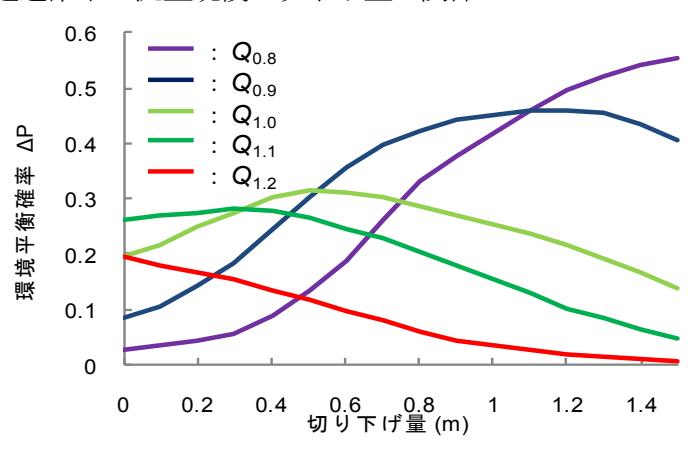

図-11 環境平衡確率と流量規模・切下げ量の関係

3) 辻本, 村上, 安井: 出水による破壊機会の減少による河道内 樹林化, 水工学論文集, 第45巻, pp.1105-1110, 2001.

4) 藤田, 李, 渡辺, 塚原, 山本, 望月: 扇状地礫床河道における 安定植生域消長の機構とシミュレーション, 土木学会論文集, No.747/II-65, pp.41-60, 2003.

5) 道奥, 宮本, 神田, 大地, 阿河, 盛岡, 魚谷, 吉田, 吉村: 樹林 化した河道の流況観測と樹林内外の流況・樹木抗力の解析, 河川技術論文集, 第16巻, pp.437-442, 2010 .

6) 前野, 宮内, 森: 植生が旭川の洪水流に及ぼす影響の検討, 水工学論文集, 第48巻, pp.757-762, 2004.

7) Kundzewicz, Z.W., et.al: Freshwater resources and their management, Climate Change 2007: Impact, Adaptation and Vulnerability, Contribution of Working Group II to the AR4 of the IPCC, Cambridge University Press, pp.173-210, 2007.

8) Weiss, G.: Shot noise models for the generation of synthetic streamflow data, Water Resour. Res., 13(1), pp.101-108, 1977.

9) Claps, P., Giordano, A., and Laio F.: Advances in shot noise modeling of daily streamflows, Advances in Water Resources, 28, pp.992-1000, 2005.

10)嚴佐庸: 数理生物学入門 一生物社会のダイナミック スを探る，改装版，共立出版, 352p, 1998.

11) Takada, T. and Iwasa, Y.: Size distribution dynamics of plants with interaction by shading, Ecological Modeling, No.33, pp.173-184, 1986.

12) Niiyama, K.: The role of seed dispersal and seedling traits in colonization and coexistence of Salix species in a seasonally flooded habitat, Ecological Research, Vol.5, No.3, pp317-331, 1990.

13) 長坂有: 河畔に生えるヤナギ類, 光珠内季 報,No.101,pp12-17,1996.

14)リバーフロント整備センター: 河川における樹木管理の手 引き, 山海堂, 204p, 1999.

15)日野，長谷部: 流量時系列のみによる流出解析について，土 木学会論文報告集, 第300号, pp.43-56, 1980.

(2010.9. 30受付) 